
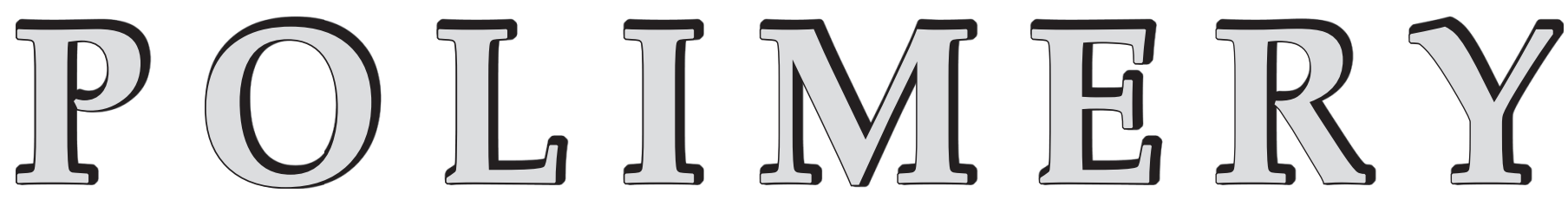

\title{
Effects of carbon nanotubes and graphene on the structure and properties of natural rubber
}

Jinyong Sui ${ }^{1)}$ (ORCID ID: 0000-0002-4232-3540), Zheng Gu' ${ }^{1), 2)}$, *) (0000-0001-9521-2863), Xiaoyi Zhang ${ }^{1)}$ (0000-0003-4047-5046), Zhenxu Li ${ }^{1)}$ (0000-0003-3998-9090), Lining Song ${ }^{1)}$ (0000-0002-5671-4745), Lina Yang') (0000-0002-5518-050X), Ning Wang') ${ }^{10000-0002-2509-3886)}$

DOI: dx.doi.org/10.14314/polimery.2021.4.1

\begin{abstract}
Natural rubber (NR) is an important strategic material for national defense industry. It is also used in the food industry and medicine. However, due to the unsaturated double bond, its aging resistance, mechanical properties and solvent resistance are very poor. In order to improve these properties, carbon nanotubes (CNTs) and reduced graphene oxide (rGO) were used, added at $1: 1$ ratio. The $\mathrm{NR} / \mathrm{CNTs} / \mathrm{rGO}$ nanocomposites were obtained by mechanical mixing after adding 1, 2, 3 and $4 \mathrm{phr}$ of filler. The influence of the filler content on the structure (TEM), vulcanization properties, abrasion and solvent resistance, mechanical properties, dynamic mechanical properties (DMA) and thermal properties (TGA) of nanocomposites was investigated. Increasing the content of CNTs/rGO increased the crosslinking density of the composites. TEM studies showed that CNTs and graphene sheets were evenly dispersed throughout the NR matrix. They also had good compatibility with the rubber matrix. The addition of CNTs and graphene increased the abrasion and solvent resistance as well as improved the mechanical properties. TGA analysis showed that the nanocomposites had excellent thermal stability. The best properties were obtained with the CNTs/rGO content of $2 \mathrm{phr}$.
\end{abstract}

Keywords: carbon nanotubes, graphene, natural rubber, mechanical mixing, nanocomposites.

\section{Wpływ nanorurek węglowych i grafenu na strukturę i właściwości kauczu- ku naturalnego}

Streszczenie: Kauczuk naturalny (NR) stanowi ważny materiał strategiczny dla przemysłu obronnego. Znajduje również zastosowanie $\mathrm{w}$ przemyśle spożywczym i medycynie. Jednak obecność $\mathrm{w}$ cząsteczce nienasyconych podwójnych wiązań powoduje osłabienie jego odporności na starzenie, pogorszenie wytrzymałości mechanicznej i odporności na działanie rozpuszczalników. W celu poprawy tych właściwości do kauczuku naturalnego w prowadzono nanorurki węglowe (CNTs) i zredukowany tlenek grafenu (rGO), dodawane w stosunku 1:1. Nanokompozyty NR/CNTs/rGO otrzymywano metodą mechanicznego mieszania NR z 1, 2, 3 lub 4 phr napełniacza (CNTs/rGO). Zbadano wpływ zawartości dodatku na strukturę (TEM), właściwości wulkanizacyjne, właściwości mechaniczne, odporność na ścieranie i działanie rozpuszczalnika, dynamiczne właściwości mechaniczne (DMA) i właściwości termiczne (TGA) wytworzonych kompozytów. Zwiększenie udziału CNTs/rGO powodowało zwiększenie gęstości usieciowania kompozytów. Z badań TEM wynika, że cząstki CNTs i grafenu były równomiernie

1) College of Chemistry and Chemical Engineering, Qingdao University, China 266071.

2) Weihai Innovation Institute, Qingdao University, China 264200.

*) Author for correspondence: guzheng596@163.com 
rozproszone w osnowie NR i wykazywały dobrą kompatybilność z kauczukiem naturalnym. Dodatek CNT i grafenu zwiększył odporność na ścieranie i działanie rozpuszczalników oraz poprawił właściwości mechaniczne naturalnego kauczuku. Na podstawie analizy TGA stwierdzono, że nanokompozyty charakteryzowały się doskonałą stabilnością termiczną. Najlepszymi właściwościami użytkowymi odznaczały się kompozyty NR zawierające 2 phr CNTs/rGO.

Słowa kluczowe: nanorurki węglowe, grafen, kauczuk naturalny, mieszanie mechaniczne, nanokompozyty.

Natural rubber (NR) is a natural macromolecular compound, mainly composed of cis-1,4 polyisoprene, which has become the most widely used rubber [1]. Rubber, steel, oil and coal together known as the world's four industrial raw materials, are the national defense industry indispensable strategic materials. Natural rubber itself has many excellent properties, such as good elasticity, excellent insulation, good wear resistance and solubility, and its water and air isolation properties are also excellent. With these excellent characteristics, it is widely used in tires, conveyor belts and sealed rubber products [2]. However, in the rubber industry, NR has a large free volume, low intermolecular bond energy and weak force, so its tensile strength, elastic modulus and tear strength are low. In most cases, it cannot meet the user demands based solely on the performance of natural rubber [3]. For example, in the application for automobile tires, its tensile tear and other mechanical properties are low, thermal stability is insufficient, wear and solvent resistance performance are low, leading to a low life of tires, frequent replacement of wasted resources, and aggravating environmental pollution. Therefore, carbon black, carbon nanotubes, graphene and other reinforcing fillers are usually added to prepare composite materials for further improvement of the rubber application performance to meet users needs. In this experiment, the properties of the composite of carbon nanotubes and graphene with NR were studied.

There are many reinforcing materials of natural rubber, among which graphene is widely used. Graphene is a monolayer graphite, which is hybridized in the form of $s p 2$. This widely used nanomaterial is a regular hexagonal honeycomb crystal, only one carbon atom thick [4]. Graphene has been widely used in the preparation of composites, supercapacitors, environmental protection, infrastructure, new energy and science and technology because of its special composition structure and excellent electrical, thermal and mechanical properties [5]. In recent years, graphene/rubber composites have been a research hotspot in the field of rubber [2]. Zhang Qi et al. [6] successfully prepared graphene sheets /natural rubber nanocomposites by adding graphene sheets as fillers to composites by mechanical blending method. The results showed that the addition of graphene sheets improved various properties of composites. Liu Quanzhong et al. [7] prepared the ternary composite material system by adding GO to powder nitrile butadiene rubber/epoxy resin composite with the three-roll grinding and dispersion technology. After analysis and characterization, it was concluded that the comprehensive performance of the composite material was improved by modifying GO.

Carbon nanotubes (CNTs) are mainly coaxial circular tubes formed by graphite sheets composed of carbon atoms arranged in a hexagonal pattern [8]. CNTs, as a one-dimensional nanomaterial, have the advantages of light weight, perfect structural connection, high strength, good toughness, excellent electric and thermal conductivity, etc. In addition, CNTs have shown good mechanical enhancement effect in the inter-layer modification of composites [9]. Therefore, carbon nanotubes (CNTS) have become nanomaterials with wide application prospects and are also a good reinforcing material in rubber field. Zhao Yanfen [10] et al. prepared hydrogenated nitrile butadiene rubber (HNBR) reinforced with nanometer dispersed carbon nanotubes by mechanical blending. The results showed that carbon nanotubes had good dispersion in HNBR matrix and could form a complete reinforcing network structure, which had excellent reinforcing effect on HNBR, and carbon nanotubes could significantly improve the tearing strength of HNBR. Mao Shiyuan et al. [11] prepared carbon nanotubes/natural rubber composites by wet mixing. Through testing of various properties, they concluded that the addition of the ground carbon nanotubes made the cosettling adhesive have better mechanical properties, and the carbon nanotubes can be well dispersed in the cosettling adhesive.

The preparation methods of reinforcing materials to enhance natural rubber composites include mechanical blending, emulsion blending, solution blending and in situ polymerization [12]. In this experiment, CNTs/ graphene /NR nanocomposites were prepared by mechanical blending method, which was simple to operate, controllable in terms of conditions, and free of solvent addition and pollution. On this basis, the composite material was tested and studied.

In this experiment, the mechanical blending method was used to prepare carbon nanotubes/graphene/natural rubber nanocomposites, to explore the ratio of carbon nanotubes and graphene for the best performance improvement of the composite material, and to explore the optimal ratio.

\section{EXPERIMENTAL PART}

\section{Materials}

Natural rubber NR (No. 1 standard glue in accordance with the shape of the manufacturing process divided into 
types of granular glue, according to the national standard for SCR5 is a standard glue), the molecular formula is $\left(\mathrm{C}_{5} \mathrm{H}_{8}\right)_{n^{\prime}}$, origin Hainan.

CNTs (carbon nanotubes), GT-304, origin Zouping Dazhan New Materials Co., Ltd., Shandong Province.

Graphene, ZnO, SA (stearic acid), $4010 \mathrm{Na}$ (rubber antiaging agent $N$-isopropyl- $N$ '-phenyl-p-phenylenediamine, molecular formula is $\mathrm{C}_{15} \mathrm{H}_{18} \mathrm{~N}_{2}$, CZ (rubber vulcanization accelerator, belongs to medium and overspeed sub sulfonamide accelerator, molecular formula is $\mathrm{C}_{13} \mathrm{H}_{16} \mathrm{~N}_{2} \mathrm{~S}_{2^{\prime}}$ $\mathrm{N}$-cyclohexyl-2-benzothiazolylsulfenamide, DM (rubber accelerator, 2,2'-dibenzothiazoledisulfide), S (sulfur) are commercially available.

\section{Preparation process of mixed rubber}

Formula of vulcanized rubber (phr): NR - 100; $\mathrm{ZnO}-5$; SA - 2; $4010 \mathrm{NA}-1$; CZ - 1.5; DM - 0.5; S - 1.5. Amount of carbon nanotubes and graphene (1:1 ratio) added: 1, 2, 3 and 4 phr.

The initial temperature in the mixer was $60^{\circ} \mathrm{C}$, the rotation speed was $60 \mathrm{rpm}$, and the filling coefficient was 0.7. Natural rubber was refining in the closed type rubber mixing machine, XN-10*30/60, Dalian General Rubber Machinery Co., LTD for a minute, and a half of the nanotubes and graphene mass were then added to the mixer, mixed for three minutes, then the other half of the carbon nanotubes and graphene was added, when the mixing temperature in the mixer reached $143^{\circ} \mathrm{C}$, the speed was adjusted to $70 \mathrm{rpm}$, the mixing was continued for 5 minutes, and then the glue was removed. The obtained rubber was mixed in the open mixing machine, XK-160B model, Shanghai Light Industry Machinery Co., LTD. After the rubber was fully rolled, ZnO, SA, CZ, 4010 NA mixture were added successively. After 10 minutes of mixing, $S$ was added, and the filler was evenly mixed and dispersed. Because of the vulcanization of natural rubber, a large number of cis-1,4 addition unsaturated structures and the use of sulfur vulcanization system is prone to the phenomenon of back vulcanization, which could damage the performance of the product [13], therefore, ZnO, SA, CZ, 4010 NA and other vulcanization promoters and anti-vulcanization reformer are added [1]. The composite rubber obtained by cutting 40 grams into the plate vulcanizing machine, QLB (350×350×2), 25 tons, Shanghai No. 1 Rubber Machinery Factory for vulcanization, the purpose is to make the rubber material temperature, rubber molecules crosslinked, from the original linear structure into a network structure, enhance its performance. Then put the vulcanized rubber sheet on the blanking machine, CP-25 model, Shanghai Chemical Machinery No. 4 Plant for punching, the purpose is to cut the vulcanized rubber sheet into dumbbell type rubber strip and install it on the electronic tension machine, DXLL-50000, Shanghai Dejie Instrument equipment Co., LTD to measure its tensile performance.

\section{Methods of testing}

\section{Transmission electron microscopy (TEM)}

The vulcanized glue was embedded with epoxy resin and ultrathin sections were placed under a transmission electron microscope (JM-2000EX, JEOL, Japan) to scan the high-magnification images and low-magnification images, respectively and observe the microstructure.

\section{Mechanical property test}

The electronic tensile testing machine (DXLL/50000, Shanghai Dejie Instrument And Equipment Co., LTD.) was used to test the tensile property of the sample according to GB/T528/1998, and the tearing property of the sample was tested according to GB530/1981. The tensile speed was controlled at $500 \mathrm{~mm} / \mathrm{min}$.

\section{Abrasion resistance test}

Roller mill (DIN/40, Yangzhou Xinhong test machine Factory) was used to test the wear resistance of vulcanized rubber according to GB-9867-2008.

\section{Determination of solvent resistance}

According to GB/T1690-92, the temperature was $27 \pm 2{ }^{\circ} \mathrm{C}$ and the soaking cycle was $4 \pm 0.5 \mathrm{~h}$.

\section{Dynamic mechanical analysis (DMA)}

The tensile method was used at a frequency of $10 \mathrm{~Hz}$, at strain level of $0.1 \%$ in the temperature range of -80 to $+80^{\circ} \mathrm{C}$ and a heating rate of $5^{\circ} \mathrm{C} / \mathrm{min}$.

\section{Thermogravimetric analysis (TGA)}

Thermogravimetric analysis was performed using a TGA/SDTA 851 (Mettler-Toledo, Switzerland). Samples of approximately $20 \mathrm{mg}$ were placed in alumina crucibles. An empty alumina crucible was used as reference. The composites were heated from $25^{\circ} \mathrm{C}$ to $700^{\circ} \mathrm{C}$ in air atmosphere, at heating rate of $10^{\circ} \mathrm{C} / \mathrm{min}$.

\section{RESULTS AND DISCUSSION}

\section{TEM analysis of prepared nanocomposites}

Figure 1 shows TEM photographs of NR/CNTs/rGO nanocomposites at low and high magnification, respectively. The gray area is NR matrix, the black linear structure dispersed in the gray area is CNTs, and the black flake structure is rGO. It can be observed (Fig. 1a) that CNTs and graphene sheets were at the nanoscale at the radial dispersion scale. Moreover, CNTs and graphene layers dispersed evenly in the NR matrix, CNTs and gra- 
a)

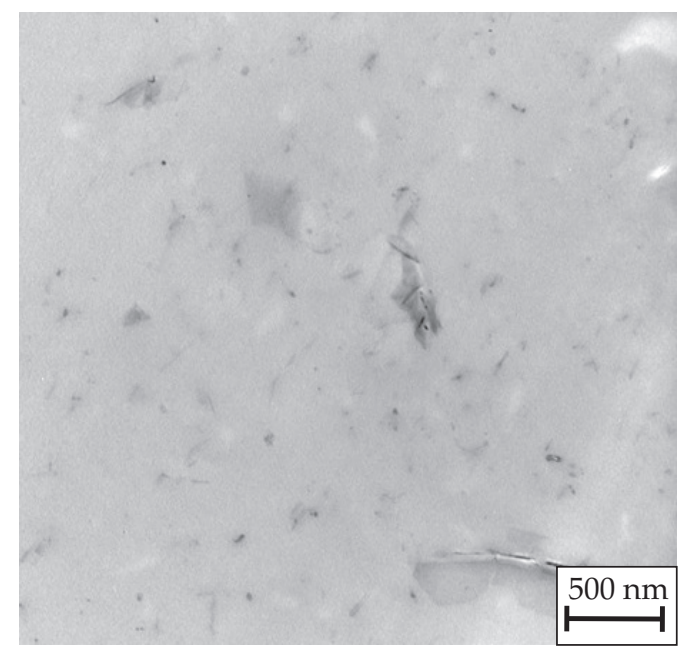

b)

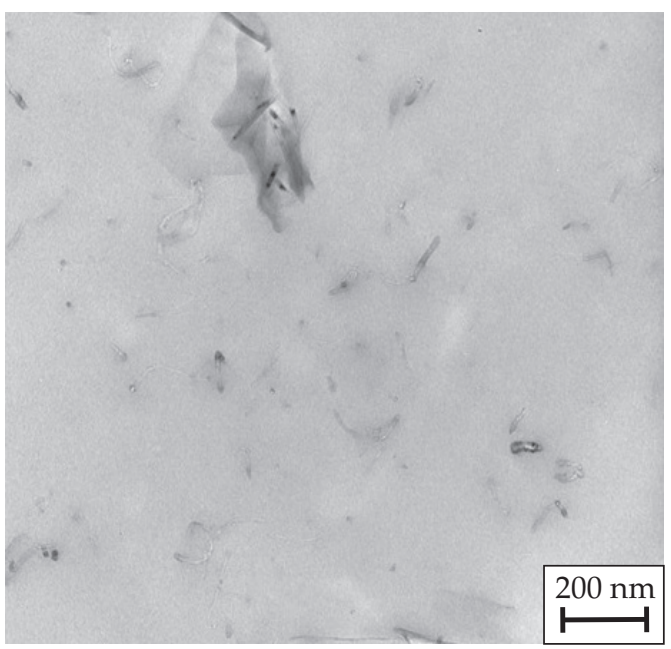

Fig. 1. TEM images of NR/CNTs/ RGO nanocomposites at: a) low b) high magnification

phene layers and NR matrix at the junction of the interface performance of fuzzy, CNTs and graphene layers and rubber good compatibility (Fig. 1b). The analysis showed that the NR/CNTs/rGO nanocomposites had been successfully obtained and CNTs were uniformly distributed in the matrix.

\section{Mechanical properties of prepared nanocomposites}

Table 1 shows the mechanical properties of NR/CNTs/rGO nanocomposites. As it can be seen, due to the increase in the content of CNTs/rGO $(1: 1)$, the properties of composites were significantly improved in terms of $300 \%$ constant elongation stress, $500 \%$ constant elongation stress, tensile strength and tear strength. The constant elongation stress is the ability of the material to resist external force under certain deformation, mainly showing the degree of the restrictive effect of the filler on the rubber macromolecular chain. The greater the constant elongation stress of the composite material, the stronger the restrictive effect of the filler on the rubber macromolecular chain [14]. According to the data, when the addition of $\mathrm{CNTs} / \mathrm{rGO}$ was $4 \mathrm{phr}$, the $300 \%$ constant elongation stress of the prepared composites increased from 2.43 $\mathrm{MPa}$ of pure NR to $4.81 \mathrm{MPa}$, and the con- stant elongation stress of $300 \%$ increased by about $100 \%$. The constant elongation stress of 500\% increased from 8.77 MPa to $16.67 \mathrm{MPa}$, and the constant elongation stress of $500 \%$ increased by about $90 \%$.The tensile strength of NR/CNTs/rGO nanocomposites was significantly improved with the increase of the content of CNTs/rGO. As can be seen from the data in the Table 1, when the content of CNTs/rGO was $2 \mathrm{phr}$, the tensile strength of the composites increased from $18.93 \mathrm{MPa}$ of pure NR to $24.74 \mathrm{MPa}$, which was about $30 \%$ higher than that of pure natural rubber. When the amount of CNTs/rGO was $4 \mathrm{phr}$, the tearing strength of composites increased from $33.55 \mathrm{kN} / \mathrm{m}$ of pure natural rubber to $48.49 \mathrm{kN} / \mathrm{m}$, which was about $45 \%$ higher than that of pure natural rubber, indicating that CNTs and rGO filling and reinforcing gave the rubber excellent properties.

Analysis showed that, by adding CNTs and graphene, have very good limit effect in the fracture of macromolecular chain of rubber. When there is an external force on the rubber macromolecular chain, the rubber macromolecular chain will form an intercalation structure with the nano-particles uniformly dispersed in the NR matrix. This kind of structure can prevent the fracture phenomenon caused by external force to a certain extent, so as to enhance the anti-tearing performance of the compound.

$\mathrm{T}$ a b l e 1. Mechanical properties of NR/CNTs/rGO nanocomposites

\begin{tabular}{c|c|c|c|c|c|c|c}
\hline $\begin{array}{c}\text { CNT/rGO } \\
\text { phr }\end{array}$ & $\begin{array}{c}300 \% \\
\text { CES* } \\
\text { MPa }\end{array}$ & $\begin{array}{c}500 \% \\
\text { CES } \\
\text { MPa }\end{array}$ & $\begin{array}{c}\text { Tensile } \\
\text { strength } \\
\text { MPa }\end{array}$ & $\begin{array}{c}\text { Tear strength } \\
\text { KN/m }\end{array}$ & $\begin{array}{c}\text { Elongation } \\
\%\end{array}$ & $\begin{array}{c}\text { Permanent } \\
\text { deformation } \\
\%\end{array}$ & $\begin{array}{c}\text { Shore hard- } \\
\text { ness } \\
\text { ShA }\end{array}$ \\
\hline 0 & 2.43 & 8.77 & 18.93 & 33.55 & 629 & 10 & 43 \\
1 & 2.64 & 9.31 & 24.02 & 38.68 & 637 & 9 & 45 \\
2 & 3.69 & 11.99 & 24.74 & 43.15 & 621 & 5 & 47 \\
3 & 3.91 & 13.60 & 21.45 & 44.58 & 576 & 10 & 48 \\
4 & 4.81 & 16.67 & 22.44 & 48.49 & 553 & 13 & 51 \\
\hline
\end{tabular}

${ }^{*}$ CES - constant elongation stress. 


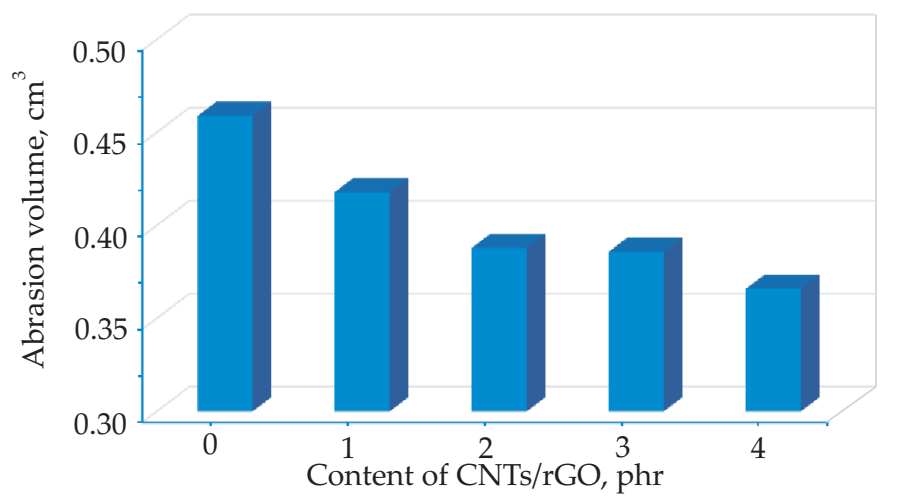

Fig. 2. Abrasion resistance of NR/CNTs/rGO nanocomposites

Therefore, NR/CNTs/rGO nanocomposites have excellent mechanical properties.

\section{Abrasion resistance of prepared nanocomposites}

Figure 2 shows the abrasion resistance of NR/CNTs/rGO nanocomposites, expressed with abrasion volume. As expected, the abrasion volume decreases with increasing content of $\mathrm{CNTs} / \mathrm{rGO}$. When the addition of CNTs/rGO was $4 \mathrm{phr}$, the abrasion volume of composite decreased from $0.46 \mathrm{~cm}^{3}$ (pure NR) to $0.36 \mathrm{~cm}^{3}(20 \%)$. The analysis shows that the wear resistance of the composite is enhanced significantly, and the wear resistance life of the rubber product based on the composite material is also significantly improved. According to the analysis, the composite after the use of CNTs/graphene can better limit the rubber macromolecular chain and have a stronger binding force with rubber macromolecules. With the increased addition of CNTs and rGO, the anti-tearing performance of nanocomposites is improved. Therefore, the abrasion resistance of NR/CNTs/rGO nanocomposites was significantly improved.

\section{Solvent resistance of prepared nanocomposites}

Figure 3 shows the change curve of the swelling index of NR/CNTs/rGO nanocomposites with the increase of the content of $\mathrm{CNTs} / \mathrm{rGO}$. As can be seen, with the addition of CNTs and rGO, the swelling index of the composite obtained showed a trend of continuous decline. When the addition of CNTs/rGO reached $4 \mathrm{phr}$, the swelling index of composites decreased from 2.98 (pure NR) to 2.41 (19\%). The results showed that the addition of CNTs and rGO significantly increased the solvent resistance of the composites.

The analysis showed that there was a strong interaction between NR matrix, CNTs and rGO, and all three were well integrated. CNTs particles and NR macromolecular chains have a strong binding force, so they have a good blocking effect on rubber macromolecular swelling. This makes the rubber molecules hard to swell. The graphene sheets were uniformly dispersed in the rubber matrix, successfully blocking the penetration and diffusion

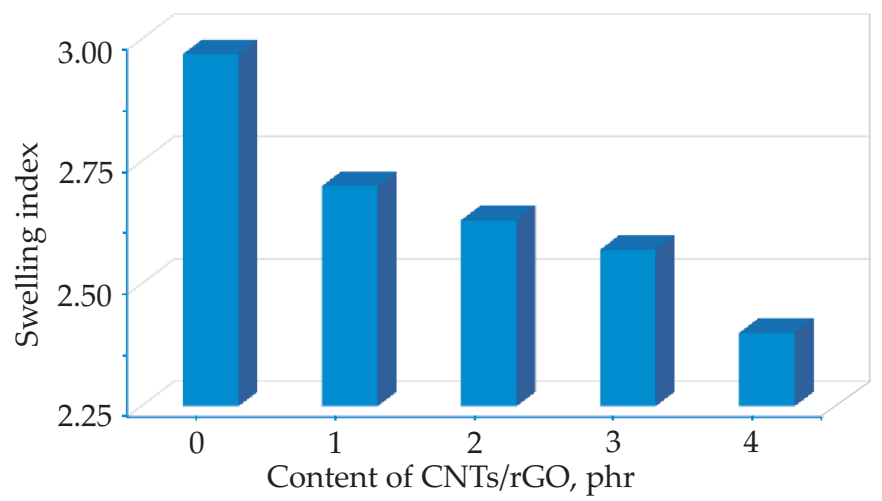

Fig. 3. Solvent resistance of NR/CNTs/rGO nanocomposites

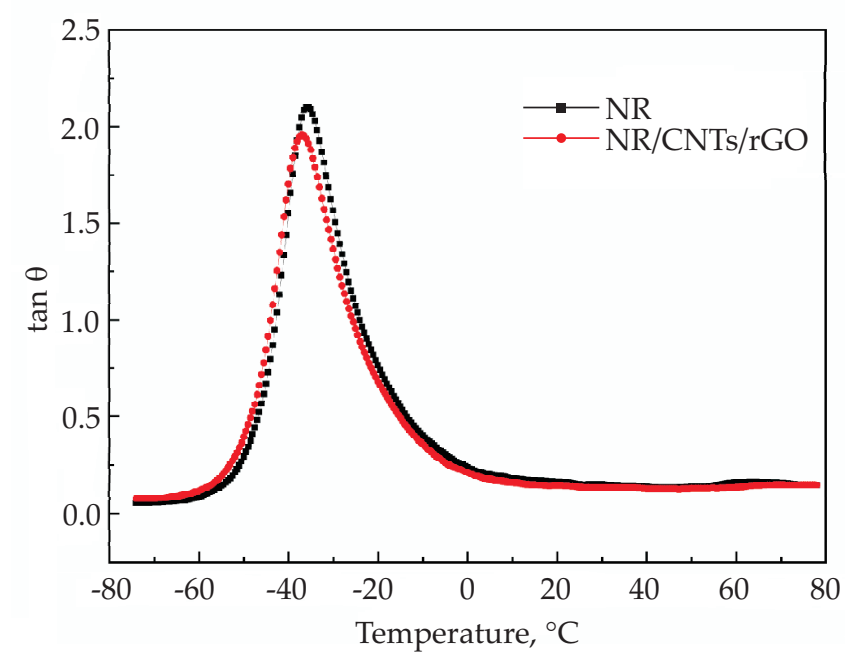

Fig. 4. Comparison of loss coefficient of NR and NR/CNTs/rGO nanocomposite

of small oil molecules into the rubber matrix. Therefore, $\mathrm{NR} / \mathrm{CNTs} / \mathrm{rGO}$ nanocomposites have excellent solvent resistance.

\section{DMA analysis of prepared nanocomposites}

The comparison of loss coefficient for NR and NR/CNTs/rGO nanocomposite as a function of temperature is shown in Fig. 4. It can be seen that the internal consumption of NR/CNTs/rGO nanocomposites was slightly lower than that of pure NR near the glass transition temperature. Moreover, the glass transition temperature difference of NR and the composite is not big. It was concluded that CNTs and graphene sheets restricted rubber macromolecular chains and thermal motion of rubber macromolecules near the glass transition temperature. According to the analysis in Fig. 4 , at $0^{\circ} \mathrm{C}$, the loss coefficient of NR/CNTs/rGO nanocomposite was similar to that of pure NR. And slightly lower than pure natural rubber at $50-60^{\circ} \mathrm{C}$. This indicates that the wetting resistance of the nanocomposite material basically does not change, while the rolling resistance decreases slightly. The lower the rolling resistance, the better the performance, thus improving the usability of rubber. 


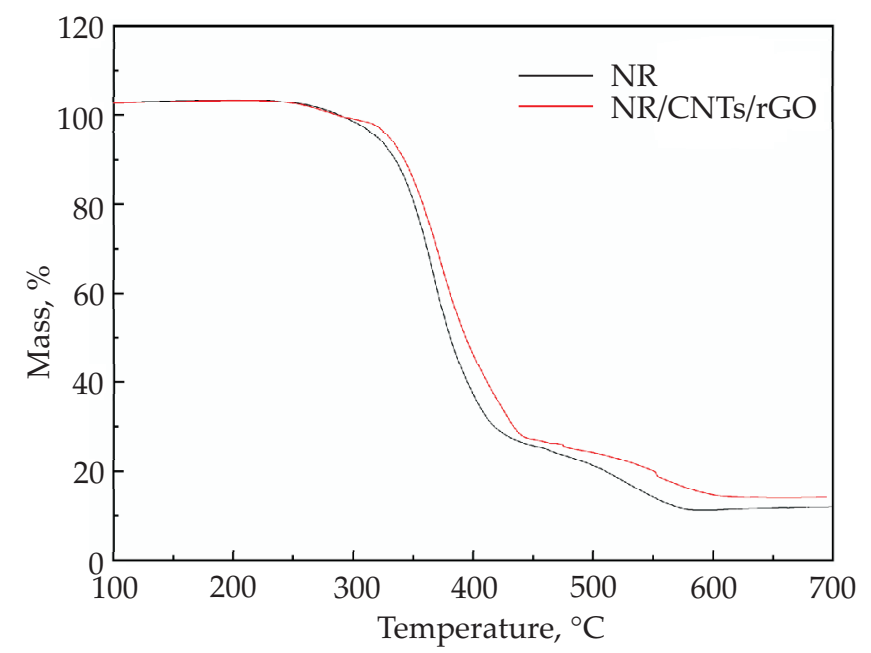

Fig. 5. The TGA curves of NR and NR/CNTs/rGO nanocomposite

\section{TGA analysis of prepared nanocomposites}

Figure 5 shows the thermogravimetric curves of pure NR (black curve) and NR/CNTs/rGO nanocomposite (red curve). As it can be seen, when the temperature is below $300^{\circ} \mathrm{C}$ the thermogravimetric curves of the rubber and the composite almost coincide, but the difference is not significant. When the temperature is higher than $300^{\circ} \mathrm{C}$, the thermal decomposition temperature of pure NR was significantly lower than that of NR/CNTs/rGO nanocomposite. At the same temperature, the thermogravimetric ratio of NR/CNTs/rGO nanocomposite was small. When the addition of $\mathrm{CNTs} / \mathrm{rGO}$ was $2 \mathrm{phr}$, the temperature of the maximum thermal degradation rate of NR/CNTs/rGO nanocomposite increased from $368^{\circ} \mathrm{C}$ to $373^{\circ} \mathrm{C}$, and the analysis showed that the thermal stability of the composite was significantly enhanced. According to the analysis, the air atmosphere used in this experiment, CNTs and graphene sheets are excellent barriers to gas diffusion and permeability. At the same time, it also has a certain blocking effect on the infiltration of oxygen molecules into the rubber matrix. In addition, it can also hinder the migration of inflammable small molecules generated during the decomposition of materials from the inside to the outside and delay the thermal decomposition of composites [15]. Therefore, the NR/CNTs/rGO nanocomposite prepared had good thermal stability.

\section{CONCLUSIONS}

Both carbon nanotubes and graphene have a good influence on rubber properties, and their mechanical properties, wear resistance and solubility is significantly enhanced. CNTs and rGO were added into natural rubber at $1: 1$ ratio. CNTs and rGO were uniformly distributed in the NR matrix and had good compatibility. As the content of CNTs/rGO increased, the constant elongation stress, tear strength and tensile strength of the nanocomposites also increased. The composite after the use of CNTs/graphene can better limit the rubber macromolecular chains. The binding force of NR/CNTs/rGO nanocomposites with rubber macromolecules was stronger, and the wear resistance of NR/CNTs/rGO nanocomposites was improved. NR matrix interacts with CNTs and $\mathrm{rGO}$ and is well integrated. CNTs were bound to NR macromolecular chains. The graphene sheets are well dispersed in the rubber matrix both of them improved the excellent solvent resistance of NR/CNTs/rGO nanocomposites. Excellent gas barrier properties of CNTs and graphene sheets, delayed the thermal decomposition of composites, the thermal stability of NR/CNTs/rGO nanocomposites was enhanced. Considering CNTs and rGO at ratio of $1: 1$, the optimal content is $2 \mathrm{phr}$. The mechanical properties, wear resistance and solvent resistance of the composite materials are significantly enhanced.

In conclusion, when carbon nanotubes and graphene are added into natural rubber at $1: 1$ ratio, both of them can be evenly distributed, and at the same time, the properties of natural rubber can be significantly improved, which is the best ratio and meets manufacturers needs.

\section{REFERENCES}

[1] Yin T., Li Yin L., Sun J. et al.: Xiangsu Technology and Equipment 2020, 46 (19), 50.

http://dx.doi.org/10.13520/j.cnki.rpte.2020.19.012

[2] Zhang T., Yan X., Wang L. et al.: Chemical New Materials 2017, 45 (12), 49.

doi: CNKI: SUN: HGXC.0.2017-12-013

[3] Cui X.: Rubber Science and Technology 2018, 04, 185. doi: CNKI: SUN: XJKJ.0.2020-04-001

[4] Hong J., He X., Fu C. et al.: Chemical Propellant and Polymer Materials 2020, 6, 11. http://dx.doi.org/10.16572/j.issn1672-2191.202009074

[5] Xiao H., He Y., Chen W. et al.: Journal of Xi'an University of Arts and Sciences (Natural Science Edition) 2020, 23 (04), 80 .

doi: CNKI: SUN: XAJY.0.2020-04-017

[6] Zhang Q., Wang M., Rong W. et al.: Precision Forming Engineering 2016, 10 (02), 61.

doi: CNKI: SUN: JMCX.0.2018-02-012

[7] Liu Q., Wang X., Yang Y. et al.: Applied Chemical Engineering 2021, 50 (02), 400.

http://dx.doi.org/10.16581/j.cnki.issn16713206.20201123.028

[8] Qiu G., Xia H., Wang Q.: Polymer Materials Science and Engineering 2002, 06, 20+28.

http://dx.doi.org/10.16865/j.cnki.10007555.2002.06.005

[9] Li T., Wang S., Gu Y. et al.: Journal of Composite Materials 2021, 25 (04), 1.

http://dx.doi.org/10.13801/j.cnki.fhclxb.20201118.001

[10] Zhao Y., Su Z., Wang S. et al.: Elastomer 2020, 30 (03), 41. 
http://dx.doi.org/10.16665/j.cnki.issn10053174.2020.03.009

[11] Mao S., Zhang X., Zhang X. et al.: Xiangsu Technology and Equipment 2020, 46 (15), 1. http://dx.doi.org/10.13520/j.cnki.rpte.2020.15.001

[12] Yap P.L.; Kabiri S.; Auyoong Y.L. et al.: ACS Omega 2019, 4 (22), 19787.

http://dx.doi.org/10.1021/acsomega.9b02642

[13] Fan R.L., Zhang Y., Zhang Y.X. et al.: Tire Industry 2001, 05, 280. doi: CNKI: SUN: LTGY.0.2001-05-007

[14] Tan Y.J., Liang Y.R., Zhang L.Q.: Rubber Industry 2006, 053 (007), 393. doi: CNKI: SUN: XJGY.0.2006-07-002

[15] Gu Z., Luo P., Song G. J. et al.: Rubber Industry 2011, 58 (03), 167.

doi: CNKI: SUN: XJGY.0.2011-03-012

Received 4 XII 2020. 